\title{
THE IMPLEMENTATION AND THE STUDENT'S RESPONSES OF GUIDED QUESTION TECHNIQUE IN TEACHING WRITING RECOUNT TEXT
}

\author{
Sinta Pertiwi ${ }^{1}$, Evie Kareviati ${ }^{2}$ \\ 1,2 IKIP Siliwangi \\ ${ }^{1}$ spertiwi28@ student.ikipsiliwangi.ac.id, 2 ekareviati@ gmail.com
}

\begin{abstract}
The research is aimed to investigate the implementation and to find out student's responses to the guided questions technique in teaching writing recount text. The research used descriptive qualitative method. The data was obtained from observation and questionnaire. The research was conducted at SMPN 5 Cimahi which the participant was the 35 students of VIII - G. The result of the research showed that the guided question technique was implemented under the theory. It can be seen from the use of basic questions to gathering the ideas and the steps of implementing the guided question technique were done while the teaching-learning process. Guided questions technique also helps students in understanding the material. Meanwhile, the students gave a positive response toward the guided questions technique's implementation with $76.3 \%$ of students agree that the guided question technique is interesting and easy to use. Moreover, with the average $97 \%$, attention aspect being the highest average indicator which can be illustrated that the guided questions technique was interesting and enjoyable.
\end{abstract}

Keywords: Writing, Recount Text, Guided Question, Student's Response

\section{INTRODUCTION}

Writing is one of the four basic skills, including listening, speaking, and reading. In the writing process, students are required to deliver their ideas to others in written form. Graham (2006) as cited in Parmawati, Santoso, \& Yana (2020) states that students have to struggle significantly with writing and if someone does not write well he will find difficulties in the process of learning, education, andwork. Supported by Nunan (2003) cited in Indriani, Zahrida, Hardiah (2019:217) who stated that writing is a mental work of inventing the ideas, thinking about how to express and organizing them into statement and paragraphs that will be clear to the reader. Writing also used as a first step in doing something. In line with Harmer (2007) in Indrasari and Julita (2018:160) stated that "Writing is frequently useful as preparation for some other activity, in particular when students write a sentence as a preamble to discussion activities". Furthermore, writing is a skill to deliver the ideas, thought and feeling through a written form to communicate with other.

Meanwhile, recount text is one genre that taught to students besides the descriptive text, procedure text, and narrative text. Recount text defined as a text which is retelling about what happened in the past. Then, Garot and Wignell (1994) cited in Suryati \& Hazairin (2018) stated that "the social function or purpose of recount text was informing or entertaining". From the definition and social function, recount text used to entertain or inform readers by retelling about an events that occurred in the past. Moreover, there is the generic structure of the text included orientation, series of events, and re-orientation. Suryati \& Hazairin (2018) stated that at the beginning of the recount text or orientation section was told who was involved, what happened, 
where the event took place, and when it happened. Then, telling every event which was happened in a series of paragraphs. At the end of the text was a concluding paragraph or reorientation. Then, Boardman (2008) in Saragih, Silalahi, \& Pardede (2014:57) cited in Asni and Susanti (2018:134) concluded that recount text was focused on the individual participant by used noun and pronouns, used past tense and conjunction to describe series of event, adverbs and adverbial phrases used to describe place and time of the text.

Furthermore, in the teaching-learning process the students may give responses toward the implementation of technique, media, or approach that used by the teacher. The responses of the students also affected the student's outcomes. The response is "Coordinated movement by one's perception towards any events in the environment" (Hamalik, 2011) in Muhlisin (2018:14). The responses can be seen by student's expression, comment or enthusiasm, difficulty degrees, even by how students listening to the teacher's explanation (Riyana \& Susilani (2007) cited in Muhlisin (2018:14). The student's responses can be positive or negative. The students with positive responses will tend to like and pay attention to the learning process, while the students with negative responses will tend to dislike and ignore it. The responses of the students may affect the student's motivation to learn. Hence, motivation also can affect a student's writing.

Moreover, writing became a most difficult skill because writing is not only about putting the word into a sentence or paragraph but also the writer should have good grammar, can organize the ideas into the logical interconnection between each other and made the result of writing process worthy and understood by the readers. Then, the writer also needs a broader knowledge, emotion, and even precious time to made good writing (Darmawan and Andrianti, 2018:54). Other opinion delivered by Tangpermoon (2008) cited in Resmana \& Anggraeni (2018:87) stated that writing was known as the most complicated skill, the reason is the skill need correct language use or specific vocabulary. Meanwhile, less motivation to write also became a problem in writing. In line with Indrasari and Julita (2018:163) stated that student's problem of writing is have not bravery to writing, the students often rearrange the sentence from the text or copied from the students who were good at English. Based on that statement, the students felt not confident with their ability to write. The lack of knowledge also made students had less motivation to write.

From the paragraph above, it is important to find an appropriate solution to help students in writing recount text bravely and maintain the ideas into good writing. Hence, the researcher interested in using guided questions technique to solve the problem and also want to know how the student's responses toward this technique. Guided questions technique is a technique which used several questions to help the writer in developing the ideas. The questions used as a framework for writing. In line with Traver (2018) cited in Indrasari and Julita (2018:164) guided questions as a direction to find understanding by used the basic question. Then, Giacomozzi (2007:1) as cited in Darmawan and Andrianti (2018:56) stated "Questioning techniques are a key element of an interactive classroom which is constantly being invented and revised to help facilitate active learning."

Moreover, by providing several questions. Guided questions technique outlined guide in the writing process. Supported by Brown (1988:235) cited in Indrasari and Julita (2018:165) stated the guided question technique used to push the writer to write from an outline. Meanwhile, White (1986) in Indrasari and Julita (2018:165) called guided question technique by 5Ws and the $\mathrm{H}$ grid. The questions including What, Where, When, Why, Who, and How. Those question needed to know the topic. Afterward, adopted on Gould (1989) cited in Hariyanto (2018:78) here were some functions of guided questions technique as follows: 
1. Guided question displaced the writer from observing simple physical details to discovering complexities inherent in a topic and it is the environment.

2. Guided questions encourage the writer to re-evaluate the writer's understanding of a topic and see it differently.

3. The writer can generate materials for writing.

4. The writer can see the topic from a different point of view.

5. Guided questions may help the writer to clarify the position in a topic.

In teaching English by using guided questions technique that was some steps as follows:

1. The teacher gave a topic.

2. The teacher-guided the students in gathering the ideas

3. The teacher provided several questions related to the topic

4. The teacher asked the students to answer all the questions

5. After answering the questions, the teacher asked the students to transferred the answer of the question into a paragraph.

6. The teacher asked the students to check and revise the paragraph.

7. The teacher gave feedback to the students

Adapted from Hariyanto (2018:79).

Meanwhile, some research has been conducted about the guided questions technique. Indrasari and Julita (2018) stated that the students reached a higher score after got treatment by using a guided questions technique. It showed there is a significant influence of guided question technique toward student's writing descriptive text, Then, Hariyanto (2018) stated that at the end of the research of using guided questions technique was influence the student's procedure text writing ability. Later, Indriani, Zahrida, and Hardiah (2019) stated that guided questions technique is an interesting technique to improve student's writing ability and also gave a positive effect on student's writing skills. From the research before, it was believed that the guided questions technique can help to increased student's writing ability.

From the paragraph above the purpose of the research was to investigate the implementation and find out the student's responses of guided question technique in teaching writing recount text.

\section{METHOD}

This research used descriptive qualitative research. It was chosen because this research describes existed conditions in the field by gain information about a certain phenomenon. Qualitative research was used to understand the participant's standpoint of the event, situation, and actions that they were involved with (Cresswell (2003) cited in Setyarini (2018:389). Then, Atmowardoyo (2018:198) stated that the descriptive method used to explain as accurately as possible the real phenomenon. Furthermore, Lambert \& Lambert (2012) cited in Nurmalasari \& Apsari (2019:16) stated that "qualitative descriptive research should be seen as a categorical, as opposed to a non-categorical, alternative for inquiry." Also, descriptive qualitative research can be presented with the data from existing phenomena under reality.

This research was conducted at SMPN 5 Cimahi with the participant was the students of VIII $\mathrm{G}$ which was consist of 35 students. The data were collected from observation and questionnaire. According to Marshall \& Rossman (1998:7) cited in Nurmalasari \& Apsari (2019:16) observation is the systemic description of the events, behavior, and artifact of a social setting. The observation used to obtain information on the implementation of the guided questions technique during the teaching-learning process in three meetings. Besides, the 
questionnaire is an activity to provided and allowed the students to state the feeling and perception toward something. The researcher used a questionnaire developed by Muhlisin (2017) as cited in (Muhlisin, 2018). The questionnaire was given at the last meeting after all the implementation of the guided question technique. It used to fnd out the responses of students toward the implementation of guided questions technique in writingg recount text.

\section{RESULTS AND DISCUSSION}

\section{Results}

\section{Observation Result}

In the first meeting, the lesson began at 10.30 a.m. until 12.00 a.m. The teacher focused on recount text. The teacher provided a text of recount text on the screen. The text is about someone's holiday. The students read the text and tried to understand the meaning of the text. Then, the teacher explained the recount text, including the meaning, social function, generic structure, and language features. The teacher also gave students the opportunities to ask related to the recount text. The students gave a positive responses while the lesson process. After that, the teacher asked the student's understanding of recount text by gave several questions. Some students could answer easily, while some of them looks afraid to answer or could not answer without the teacher's help but the students feel enthusiastic attending the lesson. Then, the students have to identify the generic structure, language features, and generic structure of the text. The past tense was one of the student's problem while the lesson process. Then, the teacher gave several questions related to the video to checked the understanding and reminded the students about what they be learned.

The second meeting was held from 10.30 a.m. until 12.00 a.m. In this meeting, the teacher started to used the guided questions technique to help student's understanding of recount text. The lesson began with the teacher providing a video about recount text. The video telling about someone's holiday. In this video, the students need to know what the story about and how the story happened. The student's reaction was good, it reveals with good attention while video playback. The student's understanding was checked by the teacher's questions. Some of the students could not answer the question and need to watch the video again. After that, the teacher replayed the video to reminded students about the answer to the question. Then, the students could answer the question. After that activity, the teacher starts to use the guided questions technique by providing several questions related to the video as a task. Here, the list of the question as follows:

1. What is the story about?

2. Who is the participant?

3. Where did the story take place?

4. When did the story happen?

5. How is the chronology of story?

6. Why the story is told?

The teacher explained how to used a guided question technique. The teachers want the students to answer the question. Then, displace the answer in the column of the recount which is to identify the generic structure of the text. Guided question technique used to identify the aspects of the video. Here was the column text task.

Table 1. The Students Column Task

\section{Titles}

\section{Orientation}




\begin{tabular}{l}
\hline Series of Event \\
\hline Reorientation \\
\hline
\end{tabular}

The teacher also guiding the students to displace their answers into the column. Here guided question technique used as a guide in deciding which the appropriate answer to inserted into the right column. Unconsciously, the students can retell the story from the video into written form.

In the third meeting, the teacher was asked the students about their unforgettable experiences. The students gave positive responses related to the topic. The teacher asked the students to make a recount text related to the topic. The students used guided question techniques like the last meeting, to help the students write the recount text. First, the questions were prepared, the list of the question was made like in the last meeting. The questions used in generated student's ideas related to the topic. After that, the students could answer the question based on the student's experience. Later, the student's answer had to transform into the paragraph of recount text. After finished made a recount text, the students have opportunities to revise or recheck their work before collected. In the end the papers were collected.

\section{Questionnaire Result}

The questionnaire used to gain student's responses after the implementation of the guided question technique while the teaching-learning process. Here the result of the student's responses questionnaire grid.

Table 2. Student's Response Result Questionnaire Grid

\begin{tabular}{lllclc}
\hline No & Indicator & \multicolumn{1}{c}{ Statement } & $\begin{array}{c}\text { Strongly } \\
\text { Agree \& } \\
\text { Agree }\end{array}$ & Neutral & $\begin{array}{c}\text { Disagree } \\
\text { \& } \\
\text { Strongly } \\
\text { Disagree }\end{array}$ \\
\hline $\mathbf{1}$ & Attention & $\begin{array}{l}\text { Guided questions technique } \\
\text { interesting to used }\end{array}$ & $100 \%$ & & \\
\hline $\mathbf{2}$ & & $\begin{array}{l}\text { Guided questions technique helps to } \\
\text { eliminate errors in writing }\end{array}$ & $94.29 \%$ & $5.71 \%$ & \\
\hline $\mathbf{3}$ & & $\begin{array}{l}\text { Guided questions technique helps to } \\
\text { remind of recount text subject. }\end{array}$ & $97.14 \%$ & $2.86 \%$ & \\
\hline $\mathbf{4}$ & Relevance & $\begin{array}{l}\text { Writing more easily with guided } \\
\text { questions technique }\end{array}$ & $74.3 \%$ & $25.7 \%$ & \\
\hline $\mathbf{5}$ & & $\begin{array}{l}\text { Writing more fun with guided } \\
\text { questions technique }\end{array}$ & $62.9 \%$ & $37.1 \%$ & \\
\hline $\mathbf{6}$ & $\begin{array}{l}\text { Guided questions technique made } \\
\text { recount text more understandable }\end{array}$ & $85.71 \%$ & $11.43 \%$ & $2.86 \%$ \\
\hline $\mathbf{7}$ & Confidence & $\begin{array}{l}\text { Guided questions technique made } \\
\text { the writing confidently }\end{array}$ & $71.5 \%$ & $25.7 \%$ & $2.8 \%$ \\
\hline $\mathbf{8}$ & $\begin{array}{l}\text { Guided questions technique made } \\
\text { more passionate to write }\end{array}$ & $65.74 \%$ & $31.4 \%$ & $2.86 \%$ \\
\hline $\mathbf{9}$ & Satisfaction & $\begin{array}{l}\text { Guided questions technique gave } \\
\text { freedom in writing }\end{array}$ & $71.44 \%$ & $25.71 \%$ & $2.85 \%$ \\
\hline
\end{tabular}




\begin{tabular}{|c|c|c|c|c|}
\hline 10 & $\begin{array}{l}\text { Guided questions technique does not } \\
\text { provide satisfaction on the outcome } \\
\text { of the writing }\end{array}$ & $40 \%$ & $22.86 \%$ & $37.14 \%$ \\
\hline & Average & $76.302 \%$ & $18.85 \%$ & $4.85 \%$ \\
\hline
\end{tabular}

From the questionnaire, results reveal that most of the students agree that the guided question technique can be used in teaching writing recount text. In detail each statement had a greater value on column of strongly agree and agree. Furthermore, the researcher also categorized the average student's response in each indicator. The indicator was attention, relevance, confidence, and satisfaction. Each indicator in the questionnaire can show the tendency of student's responses toward guided questions technique. The student's positive response in each indicator was calculated to refer to the average value in each indicator.

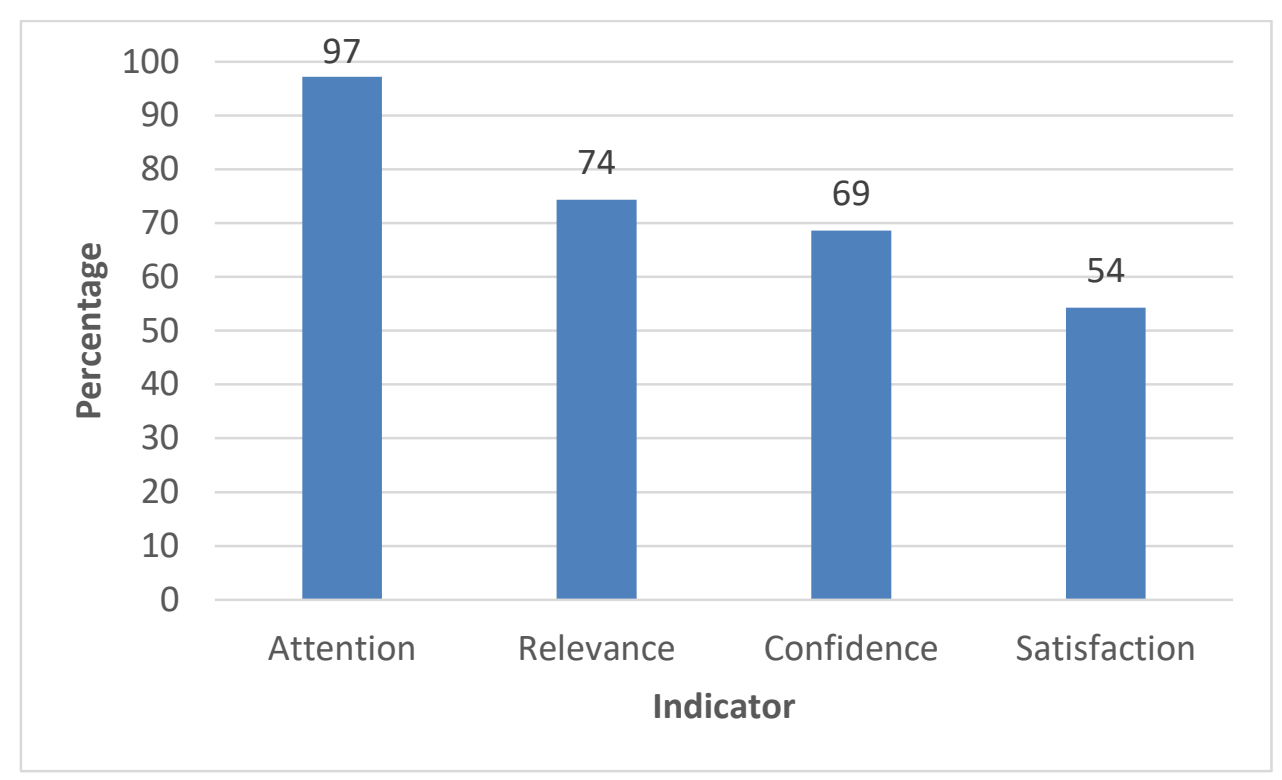

Figure 1. Average of Student's Response in Each Indicator

Based on figure 1. the attention aspect is the highest average with an average of $97 \%$. The relevance aspect with an average $74 \%$ at the second, confidence aspect with an average $69 \%$ at the third and the lowest was satisfaction aspect with an average 54\%. Good attention can be seen in the teaching-learning process, the students feel enthusiastic and gave more attention to the lesson. It was correlated with the high value of student's response to the attention aspect.

\section{Discussion}

Based on the observation result, the understanding of recount text is very important as basic knowledge in made a recount text. Social function, generic structure, and language features were the main part that must be mastered. Garot and Wignell (1994) cited in Suryati \& Hazairin (2018) stated that recount text used to retelling what happened in old times to inform and entertain the readers. Mastery of basic knowledge of recount text also helps students to deliver the ideas as clear as possible.

Afterward, the implementation of the guided question started from the second meeting until the last meeting. The teacher used a guided question technique to guide the students in organizing the ideas into the text form. Where, the students retell the story from the video and their ideas into a recount text. As Brown (1988:235) cited in Indrasari and Julita (2018:165) stated that the 
guided question can be outlined to write The outline from the questions used to the writing process easier. However, the question also used to check student's understanding while identification of the story. It was supported by Traver (2018) cited in Indrasari and Julita (2018:164) stated that basic questions used as guidance to discover understanding.

Also, students helped by answered questions from guided questions technique in developing student's ideas. Gould (1989) cited in Hariyanto (2018:78) stated that by guided question the writer can generate the material of writing. This reason increased student's confidence in writing. The students will not felt confused in made a story, because the question may guide them to organize the story. Moreover, by answering the question of guided questions technique, students can maximize the time and the ideas can be more organized in writing recount text. Then, adapted from Hariyanto (2018:79) the implementation's steps of guided questions technique were done. Which are the stages including providing a topic and questions related to the topic, then gave the students opportunities to answer and displace their answer into the form of a paragraph. Students revising and checking their work and the teacher also gave feedback to the students.

Besides, from the result of the questionnaire most of the students gave positive responses. It can be seen from table 1 . Which was from ten questions the students mostly agree with the statement with the average $76.302 \%$. Where the students felt that the guided question technique can help them in writing recount text. Then, $18.85 \%$ of students stated neutral about this statement. Later, $4.85 \%$ of students did not agree to use the guided questions technique. Then, figure 1 showed the average student's response to each indicator. The highest average of response's result on each indicator was on attention aspect with an average of $97 \%$ and the lowest on satisfaction aspect with an average of 54\%. It gave an illustration that the guided question made an "enjoyable learning" which the technique is interesting to use, decreased student error, and help on the understanding of the subject matter. As Giacomozzi (2007:1) as cited in Darmawan and Andrianti (2018:56) stated that questioning technique can be made active and interactive learning. Moreover, as informed on previous research by Hariyanto (2018) stated the guided question technique gave a good effect on student's writing ability.

\section{CONCLUSION}

The research purposes were to investigate the implementation and to find out the student's response to the guided question technique in teaching writing recount text. From the observation result it reveals that the implementation of the guided question technique has been accordance with the previous theory from White (1986) cited in Indrasari and Julita (2018:165-166). Where the technique uses basic questions that are who, where, when, why, and how. And in the application, the guided question technique passes the stages addapted from Hariyanto (2018) including giving a topic, provided the several questions according to the topic, the students answered the questions, then converted the student's answer into the form of a paragraph. The questions and answers process was done in every meetings although the topic was different.

Then, the students felt enjoy while learning process and braver to write down their ideas despite the teacher's guidance still important. This technique supported the students to developed the ideas and gave another point of view in the writing process. Besides, to help in direct students writing, this technique also helps students comprehend the subject which was recount text. The questions push the students to understood and remembered the material. 
Meanwhile, $76.3 \%$ of students gave a positive response to the implementation guided question technique. Most of them felt attracted by the technique. It is supported by a high average of student's attention aspect as a result of the questionnaire that included the statement of interest to use, omit the error, and improve retention with an average of 97\%. And the lowest aspect was on the satisfaction aspect with an average of $54 \%$. The positive response also is shown by the actives and good student's attention in the learning process. It can be concluded that the guided questions technique was an interesting technique which gave a positive response from the students in writing recount text. Guided questions technique was helpful for developing student's ideas and comprehend the material.

\section{ACKNOWLEDGMENTS}

Alhamdulillahirabbil'alamin. First of all, I always thank to Allah because the writer finally finish this article. This article could not be completed without a great deal of help from many people, especially Mrs. Evie Kareviati, M.Pd. as an advisor who has provided invaluable for the guidance, patient, kindness, contribution, correcting, and helping me in finishing this journal. Without his guidance this article would not be completed well. Then for Mrs. Aseptiana Parmawati, M. Pd., who helped me from submitting to publishing this journal. Thanks are due to all people who have supported and motivated in writing this article, who cannot be mentioned one by one. May Allah blesses you all.

\section{REFERENCES}

Asni, S. L., Susanti, S., \& Sulistiyo, U. (2018). An Analysis of Grammatical Errors in Writing Recount Text at the Eighth Grade of SMP Negeri 20 Kota Jambi. International Journal of Language Teaching and Education, 2(2), 131-144. https://doi.org/10.22437/ijolte.v2i2.5205

Atmowardoyo, H. (2018). Research Methods in TEFL Studies: Descriptive. Journal of Language Teaching and Research, 9(1), 197-204. https://doi.org/DOI: http://dx.doi.org/10.17507/jltr.0901.25

Darmawan, S, L. Andrianti, A. (2018). Implementing Guided Question Technique to Increase Students' Writing Skill. 116, 54-62.

Hariyanto. (2018). The Influence of Using Guided Questions Technique Towards Students' Procedure Text Writing Ability. Journal of Research and Method in Education, 8(4), 7782. https://doi.org/10.9790/7388-0804027782

Indrasari, N. Julita, R. (2018). Guided Questions Technique for Teaching Writing Skill of Descriptive Text. Jurnal Tadris Bahasa Inggris, 11, 11(1), 1-13.

Indriani. Rizka. Zahrida. Hardiah, M. (2019). The Effect of Guided Question Technique on Students' Writing Ability in Descriptive Text. 3(2), 1-19.

Muhlisin, A. (2018). An Analysis of Students" Response of The Implementation of RMS ( Reading, Mind Mapping, and Sharing ) Learning Model in Philosophy of Science. 7(1), 13-18.

Nurmalasari, M., \& Apsari, Y. (2019). Improving Students'participation In Speaking English Using Snowball Throwing Technique. Project (Professional Journal of English Education), 2(2), 115-121.

Parmawati, A., Santoso, I., \& Yana, Y. (2020). Improving Students'writing Skill Through Round Table Technique. Eltin Journal, Journal of English Language Teaching in Indonesia, 8(2), 103-111.

Resmana, I. F., \& Anggraeni, A. (2018). The Effects of Baroque Music Exposure on Students During Writing a Narrative Text. Erudio Journal of Educational Innovation, 5(1), 87-96. 
https://doi.org/10.18551/erudio.5-1.11

Setyarini, M, N. (2018). The Implementation of Scientific Approach in Teaching With ProjectBased Learning in Teaching Recount Text. 2(1), 39-45.

Suryati, S., \& Hazairin, E. P. (2018). The Implementation of Scientific Approach in Teaching Recount Text to The Tenth Grade Students of Vocational School. 2(1), 39-45. 